\title{
THE IMPLEMENTATION OF VILLAGE FUND POLICY: A COMPARATIVE STUDY IN IMPROVING THE PUBLIC WELFARE IN TWO VILLAGES IN PATI REGENCY, CENTRAL JAVA
}

\author{
Djoko UDJIANTO ${ }^{1 *}$ \\ Abdul HAKIM ${ }^{2}$ \\ Tjahjanulin DOMAI $^{3}$ \\ Suryadi SURYADI ${ }^{4}$
}

Received: January 2020 | Accepted: February 2020 | Published: April 2020

Please cite this paper as: Udjianto, D., et. al. (2020). The Implementation of Village Fund Policy: A Comparative Study in Improving the Public Welfare in Two Villages in Pati Regency, Central Java, Holistica Journal of Business and Public Administration, vol. 11, iss. 1, pp. 87-94

\begin{abstract}
This research attempts to describe and analyse the implementation process of Village Fund in two villages in Pati Regency, Central Java. This qualitative research was conducted in Tambakromo Village and Mojomulyo Village. The result shows that the implementation of Village Fund has been in accordance with the substance of rules that underlies the village fund policy, such as how to transfer the fund, the planning, the implementation procedure, the liability, and the monitoring of the village fund. However, in their participation in the implementation of village fund policy, the actors who have big roles in allocating the village fund were the internal bureaucracy actors. Meanwhile, the participation of the local community was low. Ideally, the local community should greatly participate starting from the planning step up to the monitoring of Fund Policy.
\end{abstract}

Keywords: Implementation; Normative substance; Public welfare; Village fund policy

\section{Introduction}

Since the decentralisation of regional autonomy, the central government gives the rights, authority and responsibility for the regional government to independently organise the

\footnotetext{
${ }^{1}$ Doctoral Student Administrative Sciences, Faculty of Administrative Studies, Brawijaya University, Malang, East Java, Indonesia, udjiantodjoko@gmail.com

2 Department of Public Administrative Science, Faculty of Administrative Science, Brawijaya University, Malang, East Java, Indonesia, abdulhakim@ub.ac.id

3 Department of Public Administrative Science, Faculty of Administrative Science, Brawijaya University, Malang, East Java, Indonesia, ulin_fia@ub.ac.id

4 Department of Public Administrative Science, Faculty of Administrative Science, Brawijaya University, Malang, East Java, Indonesia, suryadi_fia@ub.ac.id

* Corresponding author
} 


\section{HOLISTICA Vol 11, Issue 1, 2020, pp. 87-94}

public and local governmental affairs. Regional autonomy has been undoubtedly strengthening the elements of regional economy by the increasing infrastructure development which powers the centres of local economic growth and the improvement of the people's basic needs service (Noor, 2012). The implementation of regional autonomy in its smallest level is the essence of independence. Village has been the pioneer of the formation of political society and government in Indonesia far before this country is formed (Widjaja, 2003).

According to the statement of Mas'ud Said (Ali, 2007), even if it is the lowest unit in the government system in Indonesia, a village is expected to have vital role, function and contribution either from public administration or social science. The reason why village become the most important unit which needs attention from the state and state bureaucracy at all level is based upon the consideration that Indonesian people mostly live in villages. Furthermore, there are many elementary problems that can only be initially solved within the regional unit in villages.

In the concept of development, as the current priority program of the government, developing Indonesia from its suburbs by empowering regions and villages in the framework of archipelagic state has changed the pattern of development from top down to bottom up. The development by involving villagers directly has shown a much better and efficient result than the one which is implemented by using project mechanism. By giving abundant opportunities to the village to organise its own household and giving authority and fund, the development that suit the people's need would be achieved.

The Village Law which is stipulated in the Law No. 6 of 2014 has put village as the vanguard of equal distribution of development and increasing the community welfare. This Law strengthens the position of village in the framework of Archipelagic State of The Indonesian Republic and as the subject of development while emphasises its function and authority as well. One of the policies that accompanies the stipulation of Law No. 6 of 2014 is the Village Fund Policy from the State Budget (APBN). This budget is transferred to the Regional Budget (APBD) of the Regency or City and given to the Village and used to fund the governance, implementation of development, and community development. The objectives of Village Fund are basically to create an inclusive economic development that can even the income.

With village fund policy, the government attempts to develop the village by supporting the improvement of physical and non-physical infrastructures of the village. With this support, it is expected that the standard of living of the villagers can be improved whereby all parties, or the villagers, can participate in developing their village. Scutariu and Scutariu (2015) stated that giving a bigger financial autonomy to local government will generate a bigger capability to serve the local community, which can have an impact on local development as well. The village government is given the rights to develop the village according to the village collective rights (Lai \& Tang, 2016). This position has a very important role in supporting the welfare of the villagers. 
HOLISTICA Vol 11, Issue 11, 2020, pp. 87-94

The study of village fund policy is a new and interesting study, seen from both the perspective of the planning of the use of village fund and its implementation. If we trace back to the history of villages in Indonesia, it was in 2015 that villages received a special attention from the central government with the initiation of Village Fund Policy. During the revolving of village fund, the government has been monitoring on field to figure out how effective the village fund policy goes. In fact, during the monitoring, there have been some misconducts reported, such as there is no development in the village, the development or procurement of service or goods does not meet the specification or budget plan, some village officials allegedly marks up the fund, there is no transparency, the community is not allowed to be involved, and fictitious projects. Those misconducts are the empirical problems which underlie the importance of evaluation for the village fund policy.

The village officials, as the basis of implementation of village government especially in the financial field, have to be able to comprehend and assign the portion in managing the village fund. Physical development is the embodiment of village development; however, nowadays the village's facilities and infrastructure are far from being sufficient in achieving the sustainable development. Therefore, funding is a basic factor in improving the village development. If we investigate objectively, there are problems occurring in Villages, i.e. lack of economic welfare in the society (Thubany, Muhimuddin \& Amir, 2006).

Based on the problems above, this research also found problems that are similar with the research object, i.e. Tambakromo Village and Mojomulyo Village where the difficulty in formulating the design and budget plan is experienced. Tambakromo Village experienced the lack of cohesiveness between head of the village and the village officials. The head of the village is not supported by the officials and the number of officials is not sufficient.

This research discusses about the implementation of village fund policy in two villages in Pati Regency, Central Java. This comparative study is intended to find out how successful the village fund policy is in improving the public welfare.

\section{Research Method}

This research used qualitative method with evaluation approach. This qualitative research is intended to understand the phenomenon that the research subject experienced, such as behaviour, perception, motivation, action etc. in holistic way and by describing a specific context naturally and by utilising multiple natural methods of (Moleong, 2007). By using evaluation approach, it is expected that accurate and objective data and information about the implementation of village fund policy can be collected based on the criteria.

This research was conducted in Tambakromo Sub-Disctrict in Pati Regency, Central Java. The locations of the research, Mojomulyo Village and Tambakromo Village, were chosen because one of them has been successful in implementing the Village Fund Policy, while the other has not. Aside of that reason, these two locations coincidentally have emotional 
HOLISTICA Vol 11, Issue 1, 2020, pp. 87-94

closeness with the researcher that facilitates the researcher to collect the necessary data and information well.

Based on the formulation of the problem and the objectives of the research, the researcher decided the following sites of the research: The Governmental Office of Tambakromo Sub-Disctrict, The Governmental Office of Mojomulyo Village, The Office of Village Consultative Body (BPD) of Mojomulyo Village, The Office of Village Community Empowerment Institute (LPMD) of Mojomulyo Village, The Governmental Office of Tambakromo Village, The Office of Village Consultative Body (BPD) of Tambakromo Village, and The Office of Village Community Empowerment Institute (LPMD) of Tambakromo Village. The key informants in this research are the Head of the Village, the Village Officials, Hamlet Officials, and the Officials of the Village Consultative Body (BPD), and the institution or parties that receive the Village Fund such as the Officials of the Village Community Empowerment Institute, the Implementation Team of Family Welfare Programme (TP PKK), the youth organisation members and the Officials of Community Group (RW) and Neighborhood Group (RT).

The researchers also collected some information from Tambakromo Sub-Disctrict and the institution in Pati Regency. The analysis of interactive data used by the researcher refers to (Miles, Huberman \& Saldana, 2014), i.e. the analysis process of data obtained in the field and moving reciprocally continuously throughout the research. The data collecting method and the data triangulation source were done to improve the credibility.

\section{Results and Discussions}

The result of this study show that the implementation of Village Fund Policy in Tambakromo Village and Mojomulyo Village has been in accordance with the normative substance of rules underlying the Village Fund Policy and there are actors who were involved in the implementation process of Village Fund policy.

\subsection{The Substance of Regulation Underlying the Village Fund Policy}

The forms of substance of regulation underlying the village fund policy based on the result of interviews from the field are how to transfer the fund, the planning, the implementation procedures, the liability, and the monitoring of the use of village fund. According to statement (Dunn, 2003) that policy implementation which is a form of practical action is different from the theoretical action of formulating the policy. Seen from the context of policy implementation, there is a close relationship with power, interest and strategy of the policy executioners, other than the characteristics of institution and regime and the permit of implementation and response towards the policy. Implementation is considered as an output (Lester \& Stewart, 2000), which is directed to reach the previously stipulated objectives (Winarno, 2008). Village Fund (DD) is a fund allocated by the Regency or City Government for villages. This fund is sourced from the part of the central and regional financial balance funds that is received by the Regency or City (Government Regulation No. 72 of 2005 Chapter 1 verse 11). 
HOLISTICA Vol 11, Issue 11, 2020, pp. 87-94

Village Fund sourced from the State Budget (APBN) is the embodiment of state recognition towards villages. The part of the central and regional financial balance funds received by the Regency or City for villages is at least $10 \%$ from the proportional distribution for each village. Village Fund aims at improving the welfare and equalisation of village development through improving the public service in villages, advancing the village economy, solving the development gap between villages and empowering the villagers as the subject of the development (Direktorat Jenderal Pembangunan dan Pemberdayaan Masyarakat Desa, 2015).

The distribution of Village Fund according to the Law No. 6 of 2014 is that all rights and responsibilities of the village and anything in the form of money and goods that is related to the implementation of rights and responsibilities can be valued by money. This rights and responsibilities can generate income, budget, funding, and management of village fund. The principle of village fund management is "Transparent, Accountable, Participation, Orderly and Discipline towards the Budget" (Regulations of Ministry of Home Affairs No. 113 of 2014). Being transparent means being open and there is nothing covered. Being accountable means holding responsibility in terms of administration, moral and law. Participation means prioritising the community participation. Furthermore, being orderly and discipline towards the budget means being consistent, punctual, and precise in number and obeying the principles (Direktorat Jenderal Bina Pemerintahan Desa, 2016). Based on the findings of the research, it was found that the use of Village Fund in Tambakromo Village and Mojomulyo Village was done in transparency. This is similar to the findings of (Zerbinati, 2012), (Heinelt \& Stolzenberg, 2014) and (Fitriyani, Marita, Windyastuti \& Nurahman, 2018) which stated that the management of Village Fund had been done in transparent, accountable, and orderly manner according to the Regulations of Ministry of Home Affairs and the law by considering the equality, legitimation, and the interest of local community.

Furthermore, the implementation process of Village Fund, especially relating to the activities that have been carried out, had been in accordance with the normative regulations, i.e. the physical and non-physical activities. $70 \%$ of the village fund was used for the empowerment of the local community, i.e. physical development of facility and infrastructure. The non-physical activity was $30 \%$ of the village fund received by the village and it was used for operational cost of the Village Government and Village Consultative Body.

The village fund is very needed in developing the village, including Tambakromo Village and Mojomulyo Village. The existing village fund was used for the village operational activity and for the empowering activities for the local community. However, in its implementation, there were problems such as inadequate fund to cover all the necessities that the village government made a policy of assigning portion to be allocated in certain facilities and infrastructure. In other words, the policy in assigning portions to a facility depended on the policy of the village officials. This circumstance might make it less objective to assign a portion of fund allocation in each activity. 
The forms of empowerment for local community such as physical development of facilities and infrastructure included the connecting infrastructure like building bridge, sewers, road and many more. The production of infrastructures included making the irrigation channels, slope, dykes, road, dams, gutters, dam and so on, while the social infrastructures were the Office of Village Government, the village meeting hall, the worship place and so on. The infrastructures of trading were village market and stalls. The facilities and infrastructures of health were village policlinic, toddler scales, tables, chairs, and so on. The result of empowering activities of local community in the form of physical development was in line with the findings of (Chasanah, Rosyadi \& Kurniasih, 2017), that the Village Fund was prioritised to finance the activities of development and empowerment for the local community. Besides, it was used for non-physical activities, which according to the implementation instruction, the village fund is used for operational fund of Village Goverment and Village Consultative Body (BPD) and the community development.

\subsection{The actors involved in the implementation process of the village fund policy}

Seen from the actors involved in the implementation process of village fund policy and their roles in Tambakromo and Mojomulyo villages, it was shown that the actors having the big roles in interacting the implementation village fund policy were the internal bureaucracy actors. There was no participation from the villagers of Tambakromo Village and Mojomulyo Village, or the participation level from the local community was low. There were only a few elite people in the village that participated, while ideally the participation from the community is needed from the planning level up to the monitoring level. The implementation implies the generation of suffice bureaucracy procedure to ensure that the policy is implemented as accurate as possible.

The statement from the field mentioned that the participation from the villagers was low or passive. In terms of planning the development activities, the village government organised a Village Discussion to decide the implementation of development. The result of this research is in line with the findings of the research conducted by (Taufiqurokhman \& Andriansyah, 2018). In the planning step, the actors have a very strategic position together with the institutional factors of the policy itself. Such interaction between the actors and institutions would later determine the process and strategy implemented by the policy community in a broader meaning. Principally, the policy actors are those who are always involved in each process of analysis of the public policy and become proactive in interacting and making interrelation in the context of public policy analysis.

Borrowing the term from Anderson's concept, in such activity, the policy actors including the internal bureaucracy actors and external actors always have a concept towards the policy. However, in Tambakromo and Mojomulyo village, the ones involved were only the internal bureaucracy actors and the elites of the village, without letting the external actors or the villagers directly involved in the activity. The lowest level of the actor participating in the Village Discussion is the head of Neighborhood Group (RT). Therefore, the community tends to agree with what has been prepared by the village government. It can 
HOLISTICA Vol 11, Issue 11, 2020, pp. 87-94

be understood that regarding the actors and their relation with the planning step of Village Fund, the executors and decision makers are only the internal bureaucracy actors. It can be seen that the villagers of Tambakromo and Mojomulyo village were governed by a small group of people who have the qualities in full social and political authority. Those who can reach the centre of authority is the best ones. They are the ones known as the elites. The villagers should be allowed to participate in this process since they are also involved in the decision-making step in this activity (Krina \& Lalolo, 2003). Nevertheless, the interaction of actors in Tambakromo and Mojomulyo village in Village Fund policy was considered dynamic. There was no clash between the villagers, even though there were only some people who had important roles. By paying attention to the diversity and approach in understanding multiple actors involved in the public policy process, the concept and context of actors strongly related to the varieties and typology of the to-beanalysed policy. In the perspective of formulating the public policy, the actors involved generally can be divided in two big groups, i.e. the internal and external bureaucracies. However, the one having main roles in these two villages was solely the internal bureaucracy actors, i.e. the village officials.

\section{Conclusions}

In implementing the village fund policy in Tambakromo and Mojomulyo villages, it can be seen that the implementation had been in accordance with the applicable substance of regulation. The village fund is used to finance the implementation of governing, developing, and empowering the local community aiming at improving the public welfare, the quality of living, and tackling poverty. The management of village finance was done in "Transparent, Accountable, Participative, Orderly and Discipline towards the Fund" manner. In each steps of disbursement of the village fund, the implementation team has to make the Fund Usage Plan (RPD) of the Village Fund, whereby the plan consists of the Recapitulation of Fund Usage Plan (RPD) and the Details of Plan in each activity. The recapitulation would later need to be signed by the Head of the Village and the Head of the Village Consultative Body (BPD). Meanwhile, the Details of Plan would need to be signed by the Head of Technical Implementation, with acknowledgement from the Head of the Village. It can be seen that the Village Fund is used for physical and non-physical activities.

There were different findings in the actors involved in the implementation of the Village Fund policy, whereby the internal actors were more dominant in the implementation while the participation level of the villagers was found to be low. Therefore, the socialization from institutional is needed so that the local community participate starting from the planning step up to the monitoring of Fund Policy.

\section{References}

Ali, M. (2007). Orang Desa Anak Tiri Perubahan. Prakarsa dan Averroes Press: Malang. 
HOLISTICA Vol 11, Issue 1, 2020, pp. 87-94

Chasanah, K., Rosyadi, S., \& Kurniasih, D. (2017). Implementasi Kebijakan Dana Desa, IJPA-The Indonesian Journal of Public Administration, 3 (2): 12-32.

Direktorat Jenderal Bina Pemerintahan Desa. (2016). Kebijakan Pengelolaan Keuangan Desa Berdasarkan Permendagri No. 113 Tahun 2014. 7 Desember 2016. www.djpk.kemenkeu.go.id.

Direktorat Jenderal Pembangunan dan Pemberdayaan Masyarakat Desa. (2015). Pokok-pokok Kebijakan Prioritas Penggunaan Dana Desa Tahun 2016. 7 Desember 2016. www.djpk.kemenkeu.go.id.

Dunn, W. N. (2003). Pengantar Analisis Kebijakan Publik. Gajah Mada University Press: Yogyakarta. Fitriyani, L.Y., Marita., Windyastuti., \& Nurahman, R.W. (2018). Determinants of Village Fund Allocation, Jurnal Akuntansi Multiparadigma JAMAL, 9 (3): 526-539. http://dx.doi.org/10.18202/jamal.2018.04.9031.

Heinelt, H., \& Stolzenberg, P. (2014). 'The Rhinish Greeks'. Bailout Funds for Local Government in German Federal States, Urban Research \& Practice, 7(2): 228-240, https://doi.org/10.1080/17535069.2014.910934

Krina, P., \& Lalolo, L. (2003). Indikator \& Alat Ukur Prinsip Akuntabilitas, Transparansi \& Partisipasi, Jakarta: Sekretariat Good Public Governance Badan Perencanaan Pembangunan Nasional.

Lai, Y., \& Tang, B. (2016). Institutional barriers to redevelopment of Urban Villages in China: A Transaction Cost Persepective, Land Use Policy, 58: 482-490, https://doi.org/10.1016/j.landusepol.2016.08.009

Lester, J. P., \& Stewart, Jr. (2000). Public Policy: An Evolutionary Approach, Second Edition, Wadswosth: USA.

Miles, M. B., Huberman, A. M., \& Saldana, J. (2014). Qualitative Data Analysis: A Methods Sourcebook, Singapore: SAGE Publications Inc.

Moleong, L. J. (2007). Metodologi Penelitian Kualitatif, Edisi Revisi, PT. Remaja Rosda Karya: Bandung.

Noor, I. (2012). Politik Otonomi Daerah untuk Penguatan NKRI, Seven Strategic Studies: Jakarta.

Peraturan Menteri Dalam Negeri No. 113 Tahun 2014 Tentang Pengelolaan Keuangan Desa.

Peraturan Pemerintah Nomor 72 Tahun 2005 Tentang Desa.

Peraturan Pemerintah Nomor 60 Tahun 2014 Tentang Dana Desa yang bersumber dari APBN.

Scutariu, A.L \& Scutariu, P. (2015). The link between financial autonomy and local development. The case of Romania, Procedia Economics and Finance, 32: 542-549, https://doi.org/10.1016/S2212-5671(15)01430-6

Taufiqurokhman, T. \& Andriansyah, A. (2018). Implementation of Allocation of Village Funds (ADD) Increases Institutional and Ngombakan Village Development Programs Manifest Good Governance, Mitra Pembaharuan, 2 (3): 197-206, doi:10.21787/mp.2.3.2018.197-206

Thubany, H., Muhimuddin, S., \& Amir, I. (2006). Desentralisasi Keuangan, Pandang Kebijakan Pemda Kepada Masyarakat Desa, Bina Swagiri-FITRA Tuban, Nuansa Aksara: Yogyakarta.

Undang-Undang Nomor 6 Tahun 2014 Tentang Desa.

Widjaja, H. A. W. (2003). Otonomi Desa Merupakan Otonomi Yang Asli dan Utuh. PT. Raja Grafindo Persada: Jakarta.

Winarno, B. (2008). Kebijakan Publik, Teori dan Proses, Med Press: Yogyakarta.

Zerbinati, S. (2012). Multi-level Governance and EU Structural Funds: An Entrepreneurial Local Government Perspective. Local Government Studies, 38(5): 577-597, https://doi.org/10.1080/03003930.2011.649914 